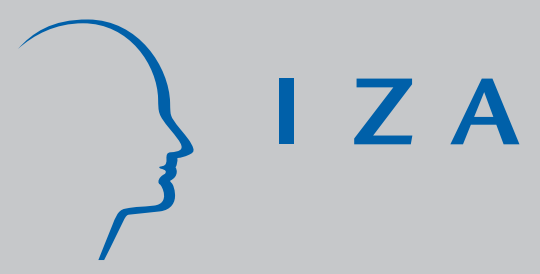

IZA DP No. 2581

Wage Flexibility and Labour Market Institutions: A Meta-Analysis

Miquel Clar

Christian Dreger

Raúl Ramos

J anuary 2007 


\title{
Wage Flexibility and Labour Market Institutions: A Meta-Analysis
}

\author{
Miquel Clar \\ $A Q R$, University of Barcelona \\ Christian Dreger \\ DIW Berlin and IZA \\ Raúl Ramos \\ $A Q R$, University of Barcelona
}
Discussion Paper No. 2581
January 2007

\author{
IZA \\ P.O. Box 7240 \\ 53072 Bonn \\ Germany \\ Phone: +49-228-3894-0 \\ Fax: +49-228-3894-180 \\ E-mail: iza@iza.org
}

\begin{abstract}
Any opinions expressed here are those of the author(s) and not those of the institute. Research disseminated by IZA may include views on policy, but the institute itself takes no institutional policy positions.

The Institute for the Study of Labor (IZA) in Bonn is a local and virtual international research center and a place of communication between science, politics and business. IZA is an independent nonprofit company supported by Deutsche Post World Net. The center is associated with the University of Bonn and offers a stimulating research environment through its research networks, research support, and visitors and doctoral programs. IZA engages in (i) original and internationally competitive research in all fields of labor economics, (ii) development of policy concepts, and (iii) dissemination of research results and concepts to the interested public.
\end{abstract}

IZA Discussion Papers often represent preliminary work and are circulated to encourage discussion. Citation of such a paper should account for its provisional character. A revised version may be available directly from the author. 
IZA Discussion Paper No. 2581

January 2007

\section{ABSTRACT}

\section{Wage Flexibility and Labour Market Institutions: A Meta-Analysis*}

Evidence during the nineties about the response of real wages to shocks highlights that this response is substantially lower in European countries than in the United States and that there are important differences among European countries. Which are the reasons that explain these different reactions? In this paper, we apply meta-analytical techniques in order to provide a quantitative summary of the available evidence regarding the influence of labour market institutions on real wage flexibility. We find that the design of the study affects the obtained results, and that in more deregulated labour markets with a lower presence of trade unions, this response is particularly larger.

JEL Classification: $\quad$ J30, J50

Keywords: meta analysis, wage flexibility, institutions

Corresponding author:

Raúl Ramos

Grup d'Anàlisi Quantitativa Regional (AQR-IREA)

Department of Econometrics

University of Barcelona

Avenida Diagonal 690

08034 Barcelona

Spain

E-mail: rramos@ub.edu

\footnotetext{
The results presented here were obtained under the contract "The contribution of wage developments to labour market performance" (ECFIN-C/2003/001) directed by Jordi Suriñach. We would like to thank the staff from the DG ECFIN (European Commission) and in particular, Michael Thiel for their comments and suggestions. Miquel Clar and Raúl Ramos also acknowledge the support from the CICYT SEJ2005-04348/ECON project. The usual disclaimer applies.
} 


\section{INTRODUCTION AND OBJECTIVES}

Inside a currency union, the exchange rate can only be used to win competitiveness against third countries but not against other countries participating in the union. In this context, one of the possible alternative adjustment mechanisms to asymmetric shocks is the role of wage flexibility as a shock absorber (Friedman, 1953). In the context of the European economic and monetary union, the role of wage flexibility is even more important due to the limitations of the other two main alternative adjustment mechanisms: migrations and fiscal transfers (see European Commission, 1997). Moreover, the economic implications of adopting the fiscal objective of zero budget balance in the medium term (as required by the Stability and Growth Pact -SGP-) for the different countries of the Euro area implies that with a given interest rate and a fixed nominal exchange rate, again, the adjustment mechanism comes down to the prescription of "wage flexibility” (see Allsop and Artis, 2003).

Wage flexibility is defined as the speed with which real wages react to macroeconomic condition and it is measured as the responsiveness of real wages to shocks, usually measured as unemployment variations. Several empirical studies carried out during the nineties have concluded that there is an insufficient response of nominal and real wages to shocks (Decressin and Fatás, 1995), in particular when compared with other monetary unions such as the United States (Blanchard and Katz, 1992). Recent studies such as Blanchard and Wolfers (2000) or Bertola et al. (2001) have highlighted the role of institutions as potential explanatory factors of these differences. In fact, other contributions (i.e, European Commission, 2003, Kandil, 2006 or Duque et al., 2006) analysing data after the structural reforms carried out in the nineties in most European countries have found that these differences are now lower than before.

Taking this into account, the objective of this paper is twofold: first, to provide a quantitative summary of the available evidence of the reaction of real wages to unemployment and, second, to analyse the influence of labour market institutions on the adjustment through wages to shocks.

With this aim, meta-analytical techniques are applied. Meta-analysis is a research methodology that is used to bring together findings from previous research on a given issue or topic, undertaken by different researchers in a succinct and systematic way. In 
fact, meta-analysis is considered a rigorous alternative to the usual narrative literature review. The main aim of this technique is thus to offer an analytical framework for research synthesis, usually based on comparative case studies, with the purpose of integrating the findings by different authors. Next, the results from the meta-analysis are used in order to analyse the influence of labour market institutions on the elasticity of real wages to unemployment.

The rest of the paper is structured as follows: the second section describes the design of the meta-analysis, next, the third section presents the empirical results, and, last, the paper concludes summarising the main findings.

\section{DESIGN OF THE META-ANALYSIS}

This section describes the different steps in the design of the meta-analysis. The first step consists of identifying the variable of interest of the analysis, next, it is necessary to identify and gather the various studies providing estimates of real wage flexibility, and last, information about the potential explanatory factors of the variable of interest must be compiled. Next, each of these steps is briefly described.

\subsection{Identification of the variable of interest}

Regarding the identification of the variable of interest, we focus our attention on real wage flexibility, as it can be understood as an indicator of adjustment to shocks throughout the labour market in the various economies. In particular, we think it is an appropriate summary of the interactions between wages and shocks. In order to set up the required database, real wage flexibility will be defined as the estimates of the elasticity of real wages to unemployment.

\subsection{Selection of studies}

A first decision regarding the selection of these studies is related to the fact that we decided to focus only on works using a macroeconomic approach as we focus on the 
analysis of labour market from this perspective ${ }^{2}$. The idea is therefore that we will select all studies when an estimate of the elasticity of real wages to unemployment is provided. It is worth mentioning that this elasticity can be defined as a short-run or long-run elasticity. These two different definitions will be controlled later in our analysis. Whenever possible, we will also collect information about the precision of these estimates (i.e. the standard error of the estimate or the t-student statistic to derive it). With regard to the geographical area considered in the study, we limited our analysis to those works considering one or more OECD countries ${ }^{3}$.

In order to look up the studies with these characteristics, we used Econlit as our primary bibliographical source. However, we complemented it using secondary sources (references in the different studies given) and web searches. It is worth mentioning that we selected published and unpublished works (i.e. working papers or communications to conferences) in order to avoid the potential effects of "publication bias" in our analysis. The studies used in the meta analysis are quoted in annex 1 . As far as the time span is concerned, we considered studies published from 1960 to the middle of 2006. However, the earliest study in our database was published in 1983 and the most recent one in 2003. Another issue to consider is whether we will include single or multiple values of the elasticity for each study. In our context, we chose to include all the estimates available in each study as the objective is merely to explain the differences in the previous results and to provide guidelines for our empirical research.

\subsection{Explanatory variables}

In the meta-analysis literature, the set of explanatory variables is usually divided into three blocks - the control variables, the variables related with the design of the study and the moderator variables.

\footnotetext{
${ }^{2}$ Nijkamp and Poot (2005) and Dickens et al. (2006) provide excellent summaries of the available evidence at the micro level. In the first study the extensive international research on the responsiveness of wages of individuals to changing local labour market conditions (wage curve) is summarised, while the second focuses on the analysis of the determinants of changes in the individuals' earnings in 31 different data sets from sixteen countries.

${ }^{3}$ The number of studies analysing real wage flexibility from a macroeconomic approach for non-OECD studies is very scarce. However, there are recent studies for the EU new member states using individual or district data on earnings such as Iara and Traistaru (2004) or Galuscak and Munich (2005).
} 
As regards the first set of variables, control variables are usually related to aspects such as the publication year, the type of publication (journal article, book chapter, report, etc.), the number of pages of each study or the number of citations received (which can be obtained from the ISI Web of Science only when the study has been published in a journal included in the Social Science Citation Index). With the sole exception of the year of publication (which could be an indicator of the state of the empirical technology when the work was done), they can be interpreted as indicators of quality of the study.

The second set of variables included some characteristics related to the design and the implementation of the empirical study that can explain the differences in the results by different authors. In our context, this list includes the following:

\section{i. $\quad$ The territory considered and the sample used}

The first aspect to take into account is the considered territory and the sample used. We defined a dummy variable for each territory considered (in the case of regions we also assigned each region to the country to which they belong in a different dummy variable), while with the sample, we recorded the first and the last year of the sample. The dimension of the territory (supranational, national and regional) was also considered.

\section{ii. $\quad$ The econometric specification}

As Broersma and Den Butter (2002) point out, traditional empirical studies on wage formation consider different variables (inflation, unemployment, productivity) to explain the determinants of the change in the wage rate (Phillips curve specification) or to explain the wage level (wage curve specification). As mentioned above, while the Phillips curve specification is based on the theoretical model of Phelps (1968), where wages are set by firms, in the wage curve approach, wages are the outcome of a bargaining process between firms and unions. From a theoretical perspective, there is nowadays some preference among economists for using a wage curve specification rather than the Phillips curve. However, some recent works such as Hsing (2001) or European Commission (2003) prefer to use a Phillips curve specification. In any event, 
it is important to stress that the results are quite similar when taking the different countries and time periods considered into account.

In the general static specification of the macroeconomic wage curve specification, real wages of country $i$ at time $t$ is explained using the following expression:

(1) $\log (R W)_{i, t}=c_{0}+c_{1} \cdot \log \left(U_{i, t}\right)+$ controls $_{i, t}+u_{i, t}$,

where $R W_{i, t}$ is the level of real wages, $U_{i, t}$ the unemployment rate in country $i$ at time $t$, and, $u_{i, t}$ is a random error term which is supposed to follow a normal distribution. Additional control variables usually included productivity, measures of competition and expected future prices. The variables enter the relationship in logs. In the Phillips curve specification, the variables are similar to those in the wage curve specification, but both are included in differences instead of in levels. It is worth mentioning that some authors do not include productivity or prices as explanatory variables while others also include lagged values of wages in order to take the effects of wage persistence into account in the analysis. In equation (1), the coefficient $c_{1}$ provides information about the reaction of real wages to an increase in unemployment, and from, an empirical point of view, it measures real wage flexibility.

Variations of the basic specification include the possibility of working with error correction mechanisms where the growth rate of wages is explained using lagged values of the growth rate of wages and the growth rate of unemployment as well as the longrun relationship between the two variables (in levels).

For this reason, we defined some dummy variables trying to reflect all these possibilities: growth rate/level of wages, growth rate/level of the unemployment rate, and the fact of including control variables in the wage equation (productivity, inflation, wage persistence).

\section{iii. Econometric methods and techniques}

Apart from differences in the econometric specification, the various authors may use different estimation methods and techniques. We defined two particular variables that reflect the differences in terms of the econometric methods and techniques applied. The 
first one is related to the consideration of a single territory or a pool of territories, while the second is related to the estimation technique applied (OLS, IV, SURE, etc). Both aspects are of course clearly interrelated.

\section{iv. $\quad$ The data set}

The data set used can also be a potential source of differences between studies. We considered the following information: the data source ${ }^{4}$, the frequency of the data, and the exact definition of wages and the unemployment rate.

The last set of variables in the meta-analysis data set is called moderator variables, and it is related to other characteristics that have not been controlled until now, such as example, the size of the different territories (in terms of population, GDP, etc. ) or other factors such as their institutional characteristics. This set of variables is also usually replaced by the introduction of fixed effects that would include all observable and nonobservable differences.

\section{EMPIRICAL RESULTS FROM THE META-ANALYSIS}

\subsection{Descriptive statistics}

After developing each of the steps described in the previous section, our database comprised 27 studies (2 books, 14 journal articles and 11 working papers) with 608 estimates of real wage elasticity or real wage rigidity. For 362 of these estimates, the standard error or the t-student was also provided. Table 1 summarises the number of elasticities obtained from each study and the number of citations received by each of these studies is also provided. By far the most frequently cited study is the one by Layard et al. (1991), with the picture provided by their estimates being that of consensus among researchers. It is also worth mentioning that the study by Payne (1995) has provided a high number of estimates (150) due to the consideration of the

\footnotetext{
${ }^{4}$ As highlighted by an anonymous referee, one difference between meta-analyses in Medicine and Social Sciences with meta-analyses in Economics is that in the first, different datasets are used (i.e., independent field studies and experiments) while in the second, studies often use closely related data sources. However, in our dataset we can find different data sources as there are several institutions providing estimates for the main economic variables (i.e, national sources, Eurostat, OECD, IMF, etc.).
} 
state-level dimension for the US. These estimates are related to 23 countries, 71 regions and 4 supranational entities. It is also worth mentioning that the 200 regional estimates were collected from only 3 studies, considering only three countries - Germany (11 regions), the UK (10 regions) and the US (50 states). The 7 supranational estimates were collected from 4 studies and involve 4 different definitions - OECD countries, the EU, the Euro area and five EU countries (Germany, France, Italy, Netherlands and the UK).

\section{-Table 1 about here-}

Table 2 provides some descriptive statistics of the estimates of real wage flexibility in our database. According to this table, the most flexible countries are Sweden, Norway, Turkey, Japan and Switzerland. There is an intermediate group formed by the Netherlands, France, Australia, Germany, Portugal, Belgium, Ireland, Italy, Luxembourg, Finland, Greece and Austria, while the less flexible ones are New Zealand, the United States, the United Kingdom, Denmark, Canada, and Spain. As it can be seen from this table, when considering the most recent studies on the topic, differences between some European countries and the United States are now lower than before.

\section{-Table 2 about here-}

If we compare these results with the only work we know that has carried out a quantitative summary of previous work, that by Heylen (1993), we can see that there are some similarities but also some differences. Heylen (1993) calculates an average of real wage flexibility for different countries using information from a considerably lower number of empirical works. In Figure 1, the relative position of the 18 countries considered by Heylen (1993) in terms of real wage rigidity are compared with the ranking obtained from the average of estimates of real wage flexibility in these countries from our database. 
Although there is a positive and significant relationship between the two rankings (after transforming them adequately, as one is related to flexibility and the other to rigidity), changes for some of the countries considered are important. This is true of Ireland, France, Germany and the Netherlands. Why are these results so different? Has the situation changed in these countries? It this result related to the fact that we included more recent studies in our database? We will now try to answers these questions using different quantitative approaches.

-Figure 1 about here-

An important methodological problem in meta-analysis is the possibility of "publication bias”. This occurs if only statistically significant results with the "correct” sign are being published. One reason might be that the editors of journals prefer to publish these "correct" results. This is one of the reasons why we tried to include not only published, but also unpublished studies (i.e. working papers). However, this does not guarantee that this problem is not present in our sample. In fact, authors may be reluctant even to circulate work if they have certain results which are not in line with previous research. With the aim of analysing the existence of publication bias in our sample, we applied a standard tool called "funnel plots". This consists of plotting the value of the variable of interest (in this case, wage flexibility estimates) against its standard error (Figure 2). The idea is to search for asymmetries in these figures. Asymmetry will indicate that studies with unequal precision disproportionately find either small or large results. In fact, without any publication bias, a symmetric funnel shape would emerge with a vertical line of symmetry at the location of the true parameter.

-Figure 2 about here-

Looking at the scatter plot in figure 2 and the estimated regression line, it seems clear that there is a positive relationship between the standard error and the estimated value of wage flexibility. In the absence of any selective reporting, this line should be horizontal, 
as the estimated elasticity should not vary in proportion to its standard error. However, if there is a tendency only to report results where the t-ratio is around 2 or greater, the reported estimated elasticity will increase as the standard error increases in order to maintain a t-ratio at or above 2 .

The evidence of publication bias should be taken into account when looking at the various studies on this topic. The predominance of results indicating a certain reaction of wages to unemployment is clear as the results predicted by economic theory. However, results indicating a non-significant relationship between wages and unemployment are certainly worrying from a policy-making point of view. Our empirical research should try to shed light on this issue.

\subsection{Results from the meta-regression}

We now present the results of meta-regressions, i.e. we estimate various regression models where the endogenous variable is the absolute value of wage flexibility and the explanatory variables are a set of variables (usually dummy ones) that reflect various study characteristics. The results of these regression models will help to identify the explanatory factors in the different results in the empirical literature on adjustment through wages and prices in the labour market.

An important issue regarding meta-regressions concerns the weight that should be given to the different publications. The quality of the various studies is not the same and, for that reason, one would like to make adjustments for quality differences. However, it is very difficult to do this without introducing subjective judgement. For this reason, we decided to use the inverse of the standard error of the estimates as weights, although this will imply that only 341 observations will be available as some studies do not report these values. Another issue that needs to be highlighted is the existence of collinearity. As mentioned above, the correlations between several potential explanatory variables are quite high and, as a consequence, the number of explanatory variables in the different models will of necessity be reduced to avoid problems derived from collinearity.

Before showing the results of the meta regressions, it is worth mentioning that when using all the observations available for real wage flexibility, the inclusion of fixed 
effects for each of the considered studies explains $26 \%$ of the variance of the absolute value of real wage flexibility. Moreover, the inclusion of country-fixed effects explains $34 \%$ of the variance of the absolute value of real wage flexibility. If we combine both sets of variables, they explain $48 \%$ of the variance of the endogenous variable.

\section{Table 3 about here}

The results of six different explanatory models of the absolute value of wage flexibility are shown in Table 3. All the estimates were obtained by applying weighted least squares using the inverse of the standard error of the estimates as weights. Taking this into account, the number of available observations is 341. It is worth mentioning that models 1, 2 and 3 are identical to models 4, 5 and 6 with the only difference that in the latter, country-fixed effects were included as explanatory variables.

From the results in this table, we can see how the dummy variable related to the fact that the study is a journal article is positive and significant at the usual levels in models 2, 3 and 4. This result is in line with previous evidence and reinforces the existence of publication bias in our data set.

The dummy variable related to territory (region) show negative values in the models where it is introduced. This result implies that when working with more disaggregated models, the value of real wage flexibility will be lower than at country level. However, when this variable is replaced by the variable related to the consideration of a single or a pool territory, this new variable is not significant.

As the choice of the database is clearly related to the level of territorial detail considered, we replaced the variables associated to territory in models 2 and 5 with those associated with the various databases. In both models, the use of national sources instead of using OECD data provides significantly different values of wage flexibility. However, these results should be taken into account due to the high correlation between the use of certain data sources and the geographical scope of the analysis. In particular, studies using regional data tend to use national sources while studies analysing several countries use OECD or Eurostat data. Moreover, only most recent studies tend to use 
Eurostat data, so probably no systematic effect could be attributed to the use of different data sources.

The evidence regarding the use of annual data or half-year instead of quarterly data does not provide any robust conclusion, as in some models the associated dummy variables are not significant and there are even some sign changes. However, the opposite happens when using hourly wages instead of annual or weekly wages. The value of the elasticity increases. This fact is in line with the results in the wage curve literature as highlighted by Card (1995).

The specification of levels or growth rates for wages and unemployment do not provide significantly different results after controlling for other variables. While the use of standardised unemployment does not seem to affect the results, the use of information concerning employees' compensation instead of wages is statistically significant. As expected, the use of ordinary least squares (OLS) or restricted least squares instead of other more complex and appropriate techniques significantly affects the estimates, although in some models this variable is not statistically significant. The introduction of control variables for inflation and wage persistence only seems to be relevant when the time period analysed is not controlled.

Finally, we prepared a set of dummy variables related to the fact that information from the 60s, 70s, 80s, 90s, and 00s is included in the sample. As we can see from the table, the dummy variables for the 70s, 90s and 00s are significant. While the sign of the coefficients are negative for the first two variables, the sign for the third is positive.

In short, we ascertained that choosing a particular database with a certain frequency and definition of variables and a given level of territorial detail, using a certain econometric technique or including some control variables, can have significant effects on empirical results.

\subsection{Evidence on the role of institutions}

In this section, we provide evidence on the role of institutions in explaining crosscountry variations in the reaction of real wages to unemployment. The idea is that the value of elasticity of wages to unemployment can be explained by the institutional 
setting. Taking into account the results by previous authors, we will considered the role of trade union densities, coverage, centralisation and coordination of bargaining, employment protection legislation, benefit replacement rates, active labour market policies and the tax wedge. The main source for these institutional data is the OECD Employment Outlook, but, in some cases, we had to merge information from this database to other such as Nickell and Nunziata (2001) or Nickell et al. (2003).

Two different approaches are going to be used. Firstly, we will consider the effects of the different institutional variables on the average value of the elasticity of wages to unemployment in the various studies) within the framework of a multiple linear regression model. Secondly, we will carry out a similar analysis, but this time controlling for the different characteristics of the studies that have been identified as relevant in the previous subsection. In particular, a two stages procedure has been applied: first, we have recovered the value of the country's various dummy variables in model 6 (which included fixed effects) and we have then specified a linear regression model with these coefficients as endogenous variables and the institutional features as explanatory variables.

In both cases, the institutional variables have been measured as means over the whole period. The results of estimating these two models by Ordinary Least Squares are shown in Table 4. It is worth mentioning that although nineteen countries have been included in the analysis, the number of observations in each of this regression is 15 due to gaps in the institutional database.

\section{-Table 4 about here-}

Both sets of results show the relevance of institutions in explaining the different responses of real wages to changes in unemployment. After eliminating the distorting effect of study characteristics, the model's goodness of fit clearly improves, reaching a value of 0.70. As far as the effects of different institutions are concerned, a higher presence of trade unions (union density) and employment protection legislation have a negative impact on the response of real wages to a change in unemployment. The coordination variable enters the equation with the opposite sign implying that a higher 
level of co-ordination will improve the response of real wages to labour market conditions. Centralisation in collective bargaining has the expected negative effect in both models, while employment protection legislation is only significant (also with a negative sign) in the second. The tax wedge is also significant with a negative sign in the first model, which implies that higher values of this variable reduce the wage response to unemployment changes, while more active labour market policies (measured as training programs) seem to extend the reaction. However, the share of public employment services has a negative effect on both models. Other variables such as the benefit replacement rate or the bargaining coverage do not have any significant effect.

\section{CONCLUSIONS}

This section summarises the main conclusions of our empirical analysis. A first conclusion is that, to our opinion, the prevailing view about differences in the reaction of wages to unemployment has been strongly influenced by the seminal contribution of Layard et al. (1991), but the picture provided when other studies are considered is slightly different.

Second, some characteristics of the studies carried out by previous authors such as the territory considered, the database used, the frequency of the data, the definition of some variables and the use of certain econometric techniques and methods are clearly interrelated.

Next, we have found that evidence of publication bias should be taken into account when looking at the different studies on this topic. The preference for results indicating a certain reaction of wages to unemployment is clear, as are results predicted by economic theory. However, results indicating a non-significant relationship between wages and unemployment are certainly worrying from a policy-making point of view. In this sense, the results of the meta-regressions permits us to state that choosing a particular database with a certain frequency and definition of variables and a given level of territorial detail, using a certain econometric technique or including some control variables, can have significant effects on empirical results. It is therefore important to 
take all this into account in order to design empirical analysis of this issue properly and to check the robustness of the results with different specifications and data sets.

Last, evidence on the role of institutions in explaining wage responses to labour market conditions show that a higher presence of trade unions (union density) and employment protection legislation implies a lower response. Other significant variables include bargaining co-ordination, active labour market policies, the degree of centralisation and the tax wedge, while other variables such as the benefit replacement rate or bargaining coverage do not seem to have significant effects.

As a final summary, it is possible to conclude that adjustment to shocks in European labour markets (which are characterised by a low mobility) is clearly influenced by institutions. In more deregulated labour markets which also have a lower presence of trade unions, the response of real wages to unemployment is particularly larger. However, the policy implications from the results are not straightforward: It is important to analyse why labour market institutions are as they are and whether there may be other reasons apart from the unfavourable impact on adjustment mechanisms which keep them as they are (European Commission, 2004). In fact, the central question is how labour market institutions should be designed in order to secure benefits, while as far as possible avoiding the distortions that provide little benefit in terms of social protection. An additional aspect to tackle into consideration is the stability of the goodness of institutions over time. In particular, the best performing institutions over a certain period of time may not necessarily be the same ones in the future. 


\section{REFERENCES}

Allsop, Christopher and Michael J. Artis (2003). The assessment: EMU, four years on, Oxford Review of Economic Policy. 19: 1-29.

Bertola, Giuseppe, Francine Blau and, Lawrence M. Kahn (2001). Comparative analysis of labor market outcomes: Lessons for the US from international long-run evidence, NBER Working Paper 8526.

Blanchard, Olivier and Lawrence F. Katz (1997). What we know and do not know about the natural rate of unemployment, Journal of Economic Perspectives. 1: 51 -72.

Blanchard, Olivier and Justine Wolfers (2000). The role of shocks and Institutions in the rise of European unemployment: the aggregate evidence, Economic Journal. 110: C1C33.

Broersma, Lourens and Frank Den Butter (2002). An Explorative Empirical Analysis of the Influence of Labor Flows on Wage Formation, Applied Economics. 34: 1583-1592.

Decressin, Jorg and Antonio Fatás (1995). Regional Labor Market Dynamics in Europe, European Economic Review. 39: 1627-1655.

Dickens, William T., Lorenz Götte, Erica L. Groshen, Steinar Holden, Julián Messina, Mark E. Schweitzer, Jarkko Turunen and Melanie E. Ward (2006). How wages change micro evidence from the international wage flexibility project, European Central Bank Working Paper 697.

Duque, Juan Carlos, Raul Ramos and Jordi Suriñach. (2006). Wages and productivity: the role of labour market institutions in OECD countries, Empirica. 33: 231-243.

European Commission (1997). Economic Policy in EMU, Part A. Rules and Adjustment and Part B. Specific Topics. Economic Papers. 124-125.

European Commission (2003). Wage flexibility and Wage interdependencies in EMU. Some lessons from the early years, European Economy. 153-194.

European Commission (2004). Labour markets in the EU: an economic analysis of recent performance and prospects, The EU Economy 2004 Review. Chapter 3.

Friedman, Milton (1953). The Case of Flexible Exchange Rates, in: Milton Friedman (ed.), Essays in Positive Economics, Chicago: University of Chicago Press: 157-203. 
Galuscak, Kamil and Daniel Munich (2005), Regional wage adjustments and unemployment: Estimating the Time-Varying Wage Curve. Finance a uver. 55: 68-82.

Heylen, Freddy (1993). Labour market structures, labour market policy and wage formation in the OECD, Labour. 7: 25-51.

Hsing, Yu (2001). A Microeconomic analysis of the impact of union wage increases on nonunion wages, Applied Economics Letters. 8: 803-806.

Iara, Anna and Iulia Traistaru (2004). How flexible are wages in EU accession countries?, Labour Economics. 11: 431-450.

Kandil, Magda (2006). Nominal wage flexibility and economic performance: Evidence and implications across industrial countries, Bulletin of Economic Research: 58: 25-49.

Layard, Richard, Stephen Nickell and Richard Jackman (1991). Unemployment, macroeconomic performance and the labor market. Oxford: Oxford University Press.

Nickell, Stephen and Luca Nunziata (2001). Labour market institutions database, version 2.00, LSE Centre of Economic Performance, http://cep.lse.ac.uk/pubs/download/data0502.zip.

Nickell, Stephen, Luca Nunziata, Wolfgang Ochel and Glenda Quintini (2003). The Beveridge curve, unemployment and wages in the OECD from the 1960s to the 1990s. In: Aghion, Philippe, Roman Frydman, Joseph Stiglitz and Michael Woodford (eds.). Knowledge, Information and Expectations in modern macroeconomics. Princeton: Princeton University Press.

Nijkamp, Peter and Jacques Poot (2005), The Last Word on the Wage Curve?, Journal of Economic Surveys. 19: 421-450.

OECD (1989). Economies in transition. Structural adjustment in OECD countries, Paris: OECD.

Phelps, Edmund S. (1968). Money-Wage Dynamics and Labor-Market Equilibrium, Journal of Political Economy. 76: 678-711. 


\section{APPENDIX: LIST OF STUDIES INCLUDED IN THE META-ANALYSIS}

Alogoskoufis, George and Alan Manning (1988). On the Persistence of Unemployment, Economic Policy. 7: 427-469.

Anderton, Robert and Ray Barrell (1995). The ERM and Structural Change in European Labour Markets: A Study of 10 Countries, Weltwirtschaftliches Archiv/Review of World Economics. 131: 47-66.

Anderton, Robert, Ray Barrell, Jan Willen in’t Veld and Nikitas Pittis (1992). Forward looking Wages and Nominal Inertia in the ERM, National Institute Economic Review. 8: 94-105.

Baddeley, Michelle, Ron Martin and Peter Tyler (2000). Regional Wage Rigidity: The European Union and United States compared, Journal of Regional Science. 40: 115142.

Bean, Charles, Richard Layard and Stephen Nickell (1986). The Rise in Unemployment: a Multi-country Study. Economica. 53: 1-22.

Bentolila, Samuel and Juan Francisco Jimeno (1995). Regional Unemployment Persistence (Spain, 1976-94), Centre for Economic Policy Research 1259

Berthold, Norbert, Rainer Fehn and Eric Thode (1999). Real Wage Rigidities, Fiscal Policy and the Stability of EMU in the Transition Phase, IMF Working Paper 9983.

Cadiou, Loïc, Stephanie Guichard and Mathilde Maurel (1999). La diversité des marchés du travail en Europe: quelles conséquences pour l'union monetaire? Parite II Les implications macroeconomiques de la diversité des marches du travail, CEPII Working Paper 10.

Elmeskov, Jergen and Maitland MacFarlan (1993). Unemployment persistence, OECD Economic Studies. 21: 59-88.

Elmeskov, Jergen and Karl Pichelmann (1993). Interpreting unemployment: the role of labour force participation, OECD Economic Studies. 21: 139-160.

European Commission (2003). Wage flexibility and Wage interdependencies in EMU. Some lessons from the early years, European Economy, pp. 153-194. 
Fabiani, Silvia and Diego Rodriguez-Palenzuela (2001). Model-Based Indicators of Labor Market Rigidity, European Central Bank Working Paper 57.

Goubert, Liesbet and Eddy Omey (1996). An Alternative Measure of Wage Flexibility, International Advances in Economic Research. 2.

Grubb, Dennis, Richard Jackman and Richard Layard (1983). Wage Rigidity and Unemployment in OECD Countries, European Economic Review. 21: 11-39.

HM Treasury (2003). EMU and Labour Market Flexibility, mimeo.

Hyclak, Thomas and Geraint Johnes (1989). Real Wage Rigidity in Regional Labor Markets in the U.K., the U.S. and West Germany, Journal of Regional Science. 29: 423432.

Hyclak, Thomas and Geraint Johnes (1992). Regional Wage Inflation and Unemployment Dynamics in Great Britain, Scottish Journal of Political Economy. 39: 189-200.

Layard, Richard, Stephen Nickell and Richard Jackman (1991). Unemployment, Macroeconomic Performance and the Labour Market, Oxford University Press, Oxford. McMorrow, Kieran and Werner Roeger (2000). Time-varying NAIRU/NAWRU estimates for the EU's member status, Economic Papers. 145.

Nymoen, Ragnar and Asbjorn Rodseth (2003). Explaining Unemployment: some lessons from Nordic Wage Formation. Labour Economics. 10: 1-29.

OECD (1999). Adaptability to Shocks: the Role of Labour Markets. In: EMU Facts, Challenges and Policies. Paris: OECD.

Payne, James E. (1995). A Note on Real Wage Rigidity and State Unemployment Rates. Journal of Regional Science. 35: 319-332.

Prasad, Eswar S. and Alun Thomas (1997). Labor Market Adjustment in Canada and the United States, IMF Working Paper 2.

Roeger, Werner and Jan in’t Veld (1997). Quest II: A Multi Country Business Cycle and Growth Model, Economic Paper. 123.

Turner, Dave, Pete Richardson and Sylvie Rauffet (1996). Modelling the Supply Side of the Major OECD Economies, OECD Economics Working Paper 167. 
Tyrväinen, Timo (1995). Wage Determination in the Long-Run, Real Wage Resistance and Unemployment: Multivariate analysis of Cointegrating Relations in 10 OECD Economies, Bank of Finland Discussion Paper 12.

Viñals, José and Juan Francisco Jimeno (1998). Monetary Union and European Unemployment, Documento de Trabajo del Servicio de Estudios del Banco de España 24. 
Figure 1: Comparison of the estimates of real wage flexibility by country with the summary analysis by Heylen (1993)

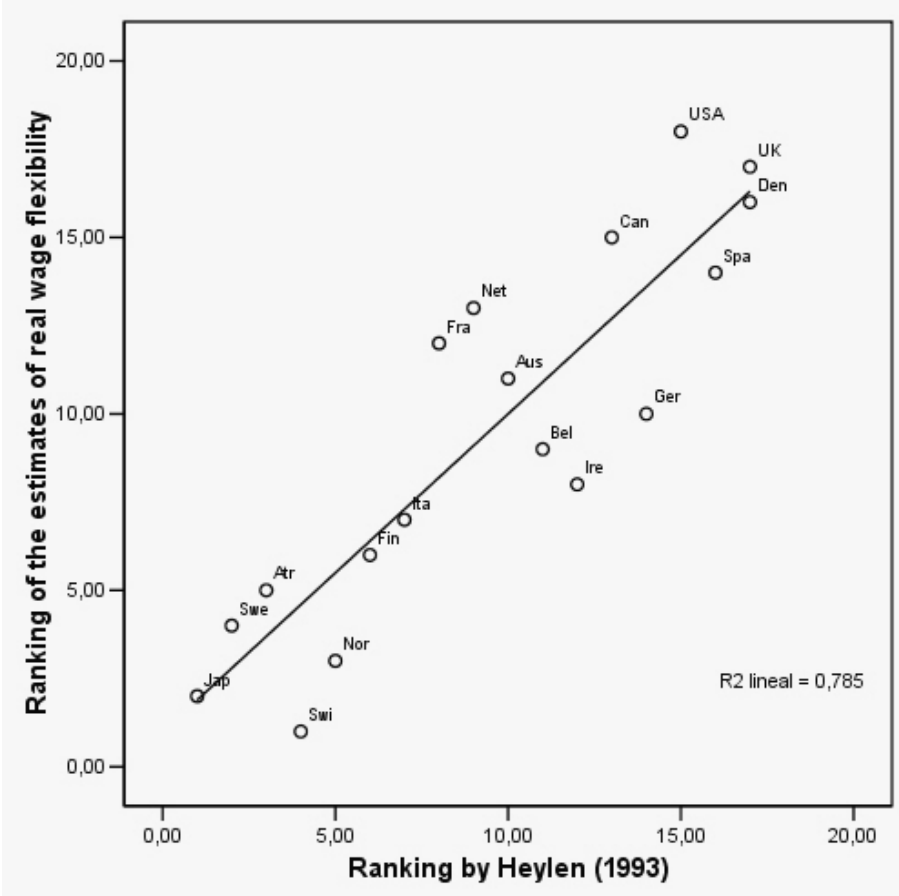


Figure 2: Relationship between the absolute value of wage flexibility and the standard error of the estimates

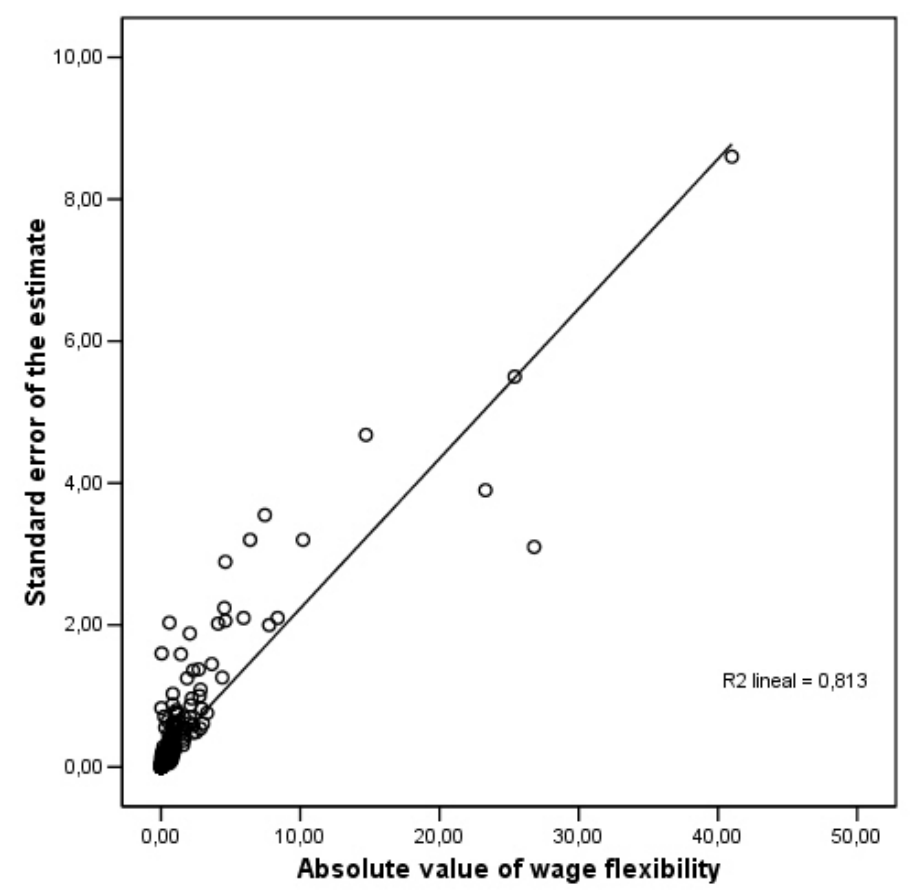


Table 1: Summary of the different studies included in the meta-analysis

\begin{tabular}{|c|c|c|}
\hline Study & Number of estimates & Number of citations* \\
\hline Alogoskoufis and Manning (1988) & 16 & 46 \\
\hline Anderton and Barrell (1995) & 10 & 5 \\
\hline Anderton et al. (1992) & 6 & 1 \\
\hline Baddeley et al. (2000) & 22 & 4 \\
\hline Bean et al. (1986) & 28 & 99 \\
\hline Bentolila and Jimeno (1995) & 1 & 2 \\
\hline Berthold et al. (1999) & 32 & 0 \\
\hline Cadiou et al. (1999) & 8 & 1 \\
\hline Elmeskov and MacFarlan (1993) & 27 & 13 \\
\hline Elmeskov and Pichelmann (1993) & 76 & 2 \\
\hline European Commission (2003) & 30 & 0 \\
\hline Fabiani and Rodríguez-Palenzuela (2001) & 14 & 0 \\
\hline Goubert and Omey (1996) & 7 & 0 \\
\hline Grubb et al. (1983) & 21 & 73 \\
\hline HM Treasury (2003) & 6 & 0 \\
\hline Hyclak and Johnes (1989) & 31 & 10 \\
\hline Hyclak and Johnes (1992) & 10 & 15 \\
\hline Layard et al. (1991) & 18 & 689 \\
\hline McMorrow and Roeger (2000) & 11 & 1 \\
\hline Nymoen and Rodseth (2003) & 4 & 0 \\
\hline OECD (1999) & 15 & 9 \\
\hline Payne (1995) & 150 & 3 \\
\hline Prasad and Thomas (1997) & 2 & 11 \\
\hline Roeger and in't Veld (1997) & 16 & 3 \\
\hline Turner et al. (1996) & 7 & 3 \\
\hline Tyrväinen (1995) & 10 & 8 \\
\hline Viñals and Jimeno (1998) & 30 & 0 \\
\hline
\end{tabular}

Source: Own elaboration.

* The number of citations was obtained from ISI Web of Knowledge at the beginning of 2006. 
Table 2: Descriptive statistics of the real wage flexibility estimates

\begin{tabular}{|c|c|c|c|c|c|c|c|}
\hline \multirow{2}{*}{ Real wage flexibility } & \multirow{2}{*}{ Observations } & \multirow{2}{*}{ Average } & \multirow{2}{*}{ Standard deviation } & \multirow{2}{*}{ Coefficient of variation } & \multirow{2}{*}{ Ranking } & \multicolumn{2}{|c|}{ Comparison with Heylen (1993) } \\
\hline & & & & & & Our ranking & His ranking \\
\hline Australia & 9 & -0.99 & 1.54 & $154.96 \%$ & 9 & 8 & 9 \\
\hline Austria & 16 & -2.17 & 2.46 & $113.22 \%$ & 18 & 14 & 16 \\
\hline Belgium & 16 & -1.07 & 0.81 & $75.69 \%$ & 12 & 10 & 8 \\
\hline Canada & 13 & -0.59 & 0.58 & $97.11 \%$ & 5 & 4 & 6 \\
\hline Denmark & 17 & -0.38 & 0.46 & $123.15 \%$ & 4 & 3 & 2 \\
\hline Finland & 11 & -1.41 & 2.02 & $142.58 \%$ & 16 & 13 & 13 \\
\hline France & 22 & -0.94 & 0.99 & $105.71 \%$ & 8 & 7 & 11 \\
\hline Germany & 23 & -1.04 & 1.10 & $106.44 \%$ & 10 & 9 & 5 \\
\hline Greece & 4 & -1.62 & 2.00 & $123.28 \%$ & 17 & & \\
\hline Ireland & 9 & -1.11 & 0.95 & $85.28 \%$ & 13 & 11 & 5 \\
\hline Italy & 22 & -1.12 & 1.25 & $111.97 \%$ & 14 & 12 & 12 \\
\hline Japan & 15 & -7.44 & 11.45 & $153.93 \%$ & 22 & 17 & 18 \\
\hline Luxembourg & 2 & -1.13 & 0.13 & $11.94 \%$ & 15 & & \\
\hline Netherlands & 15 & -0.74 & 1.01 & $137.12 \%$ & 7 & 6 & 10 \\
\hline New Zealand & 7 & -0.17 & 0.33 & $191.10 \%$ & 1 & & \\
\hline Norway & 10 & -2.68 & 3.33 & $124.20 \%$ & 20 & 16 & 14 \\
\hline Portugal & 9 & -1.06 & 0.89 & $84.08 \%$ & 11 & & \\
\hline Spain & 14 & -0.61 & 0.77 & $126.62 \%$ & 6 & 5 & 3 \\
\hline Sweden & 16 & -2.67 & 3.18 & $119.19 \%$ & 19 & 15 & 17 \\
\hline Switzerland & 9 & -7.50 & 10.19 & $135.96 \%$ & 23 & 18 & 15 \\
\hline Turkey & 5 & -6.75 & 5.44 & $80.62 \%$ & 21 & & \\
\hline UK & 26 & -0.37 & 0.51 & $138.75 \%$ & 3 & 2 & 1 \\
\hline US & 20 & -0.36 & 0.31 & $86.43 \%$ & 2 & 1 & 4 \\
\hline
\end{tabular}


Table 3: Results of the meta-regression

\begin{tabular}{|c|c|c|c|c|c|c|c|c|c|c|c|c|}
\hline $\begin{array}{l}\text { Estimates of wage flexibility } \\
\text { Weights: Inverse of std error of estimates }\end{array}$ & \multicolumn{2}{|c|}{$\begin{array}{l}\text { Model } 1 \\
\text { Coef. p-value }\end{array}$} & \multicolumn{2}{|c|}{$\begin{array}{l}\text { Model } 2 \\
\text { Coef. p-value }\end{array}$} & \multicolumn{2}{|c|}{$\begin{array}{l}\text { Model } 3 \\
\text { Coef. p-value }\end{array}$} & \multicolumn{2}{|c|}{$\begin{array}{l}\text { Model } 4 \\
\text { Coef. p-value }\end{array}$} & \multicolumn{2}{|c|}{$\begin{array}{l}\text { Model } 5 \\
\text { Coef. p-value }\end{array}$} & \multicolumn{2}{|c|}{$\begin{array}{l}\text { Model } 6 \\
\text { Coef. p-value }\end{array}$} \\
\hline Intercept & -0.57 & 0.02 & 2.37 & 0.00 & 0.76 & 0.15 & & & & & & \\
\hline Journal article (WP, Book) & 0.02 & 0.73 & 0.92 & 0.00 & 0.20 & 0.08 & 0.01 & 0.86 & 0.98 & 0.00 & 0.15 & 0.22 \\
\hline Region (Country) & -1.26 & 0.00 & & & -1.49 & 0.00 & -1.27 & 0.00 & & & -1.44 & 0.00 \\
\hline Single territory (Pool) & & & 0.23 & 0.24 & & & & & 0.11 & 0.65 & & \\
\hline National sources (OECD) & & & -0.80 & 0.01 & & & & & -0.84 & 0.02 & & \\
\hline Eurostat data (OECD) & & & 1.18 & 0.00 & & & & & 1.16 & 0.00 & & \\
\hline Annual data (Quarterly) & 0.43 & 0.00 & -0.69 & 0.04 & -0.14 & 0.62 & 0.37 & 0.01 & -0.75 & 0.05 & -0.17 & 0.57 \\
\hline Half-year data (Quarterly) & 0.03 & 0.60 & -0.76 & 0.02 & 0.22 & 0.06 & 0.05 & 0.50 & -0.76 & 0.04 & 0.19 & 0.15 \\
\hline Hourly wage (Annual wage) & 1.15 & 0.00 & & & 1.39 & 0.00 & 1.21 & 0.00 & & & 1.43 & 0.00 \\
\hline Growth rate of wages (level) & & & 0.06 & 0.43 & & & & & 0.06 & 0.51 & & \\
\hline Growth rate of unemployment (level) & & & 0.06 & 0.60 & & & & & 0.01 & 0.91 & & \\
\hline Compensation of employees (other) & & & -1.88 & 0.00 & & & & & -1.94 & 0.00 & & \\
\hline Standardised unemployment (other) & & & 0.16 & 0.66 & & & & & 0.19 & 0.62 & & \\
\hline Ordinary least squares (other) & 0.31 & 0.01 & 0.07 & 0.40 & -0.29 & 0.28 & 0.25 & 0.06 & 0.07 & 0.42 & -0.29 & 0.29 \\
\hline Restricted least squares (other) & 1.01 & 0.04 & 1.31 & 0.01 & 0.53 & 0.29 & 1.00 & 0.05 & 1.22 & 0.02 & 0.56 & 0.28 \\
\hline Control for inflation (no control) & 0.27 & 0.06 & & & -0.28 & 0.29 & 0.21 & 0.17 & & & -0.29 & 0.29 \\
\hline Control for wage persistence (no control) & 0.28 & 0.04 & & & -0.24 & 0.36 & 0.24 & 0.11 & & & -0.21 & 0.45 \\
\hline Control for productivity (no control) & 0.03 & 0.72 & & & -0.01 & 0.91 & 0.03 & 0.74 & & & -0.01 & 0.92 \\
\hline Number of observations & 0.00 & 0.37 & 0.00 & 0.63 & & & 0.00 & 0.43 & 0.00 & 0.65 & & \\
\hline 60s included in the analysis & & & & & -0.02 & 0.47 & & & & & -0.01 & 0.51 \\
\hline 70s included in the analysis & & & & & -0.40 & 0.00 & & & & & -0.36 & 0.01 \\
\hline 80s included in the analysis & & & & & 0.19 & 0.00 & & & & & 0.19 & 0.01 \\
\hline 90s included in the analysis & & & & & -0.21 & 0.00 & & & & & -0.21 & 0.00 \\
\hline 00s included in the analysis & & & & & 0.58 & 0.00 & & & & & 1.11 & 0.03 \\
\hline Unweighted $\mathrm{R}^{2}$ & 0.16 & & 0.16 & & 0.17 & & 0.28 & & 0.29 & & 0.28 & \\
\hline Weighted $\mathrm{R}^{2}$ & 0.24 & & 0.21 & & 0.28 & & 0.26 & & 0.23 & & 0.29 & \\
\hline Country Fixed effects & No & & No & & No & & Yes & & Yes & & Yes & \\
\hline
\end{tabular}


Table 4: Elasticity of real wages to unemployment and labour market institutions

\begin{tabular}{lll}
\hline & Real wage flexibility & $\begin{array}{l}\text { Real wage flexibility } \\
\text { (after controlling for study characteristics) }\end{array}$ \\
\hline Constant & 2.02 & 0.01 \\
Trade union density & $(2.15)$ & $(0.08)$ \\
Coordination in wage bargaining & -0.83 & -0.88 \\
& $(1.58)$ & $(2.19)$ \\
Centralisation in wage bargaining & -0.35 & 0.31 \\
& $(2.09)$ & $(2.65)$ \\
Employment Protection legislation & & -0.28 \\
& & $(1.97)$ \\
Tax wedge & -3.79 & -0.35 \\
Public employment services & $(2.54)$ & $(2.25)$ \\
Public employment training & 2.37 & \\
\hline R-Squared & $(1.52)$ & 2.25 \\
\hline
\end{tabular}

R-squared: Adjusted R-Squared. Absolute t-values in parenthesis. Trade union density is measured as the share of workers organized in unions, benefit replacement rates as the percentage of earnings of unemployment benefits and active labour market policies are expressed as expenditure shares in nominal GDP. Employment protection legislation, bargaining coordination and bargaining centralization are measured on a rank scale where higher numbers refer to stronger regulation. For example, bargaining coordination is scaled in the [1;5] interval, where 1 is bargaining at the individual firm level, with no coordination by higher-level associations, and 5 is coordination by top-level confederations of unions and employers associations where even the government can impose a wage freeze. 